\title{
Employees Training with References to Aqua Care Pluz
}

\author{
R. Ramamoorthy, S.S.L Mounika Gayathri, Sanjay
}

\begin{abstract}
The examination centers around human asset advancement through workers preparing and improvement rehearses. This exploration reveals insight into the connection between worker preparing and improvement rehearses with representatives' exhibition and employment fulfillment. The reason for preparing and the board projects is to improve representative abilities and association capacities. Preparing venture is returned as increasingly profitable and powerful representatives. Preparing might be centered around individual execution or group execution. These representatives are progressively dedicated towards better execution. The creation and usage of preparing ought to be utilized on preparing need examination. Preparing is a key of component for improved execution; it can build the degree of individual and authoritative competency. Preparing holds the way to open the potential development and improvement chances to accomplish a focused edge. A few proportions of execution are dissected including remuneration, execution evaluation, and authoritative duty.
\end{abstract}

Keywords: Evaluation, Renumeration, Execution

\section{INTRODUCTION}

Preparing is the way toward helping an individual for captivating his proficiency and adequacy at work by improving and refreshing his expert information by creating abilities important to his work and developing fitting conduct and frame of mind towards work and individuals. Preparing could be planned either for improving present at work or for setting up an individual for accepting higher obligations in further which would require extra information and prevalent abilities. [1],[3],[5]

Preparing is distinctive training especially formal instruction. While instruction is concerned for the most part with improvement of learning, preparing points basically at expanding information, invigorating frame of mind and granting aptitudes identified with a particular occupation. It is a persistent and deep rooted procedure[2 ],[4],[6]. Preparing gives an air of sharing and incorporating, with the assistance of the coaches, the data effectively accessible regarding the matter. Preparing is a period bound movement

Revised Manuscript Received on July 22, 2019

Mr. R. Ramamoorthy, Department of MBA, Bharath Institute of Higher Education and Research, Chennai, India. Email: ramamoorthy0071@gmail.com

S.S.L Mounika Gayathri, Department of MBA, Bharath Institute of Higher Education and Research, Chennai, India.

Email: mounika10m@gmail.com

Sanjay, Department of MBA, Bharath Institute of Higher Education and Research, Chennai, India

Email: sanjay12@gmail.com program. Therefore, there is a different specific control of mentors associating in the field of human action[7], [9],[11].

\section{RESEARCH METHODOLOGY}

Research approach is an approach to deliberately take care of the exploration issue. It is a request in to the idea of, the explanations behind, and the results of a specific situation[8],[10],[12]. It is the way toward discovering answer for an issue after an intensive report and investigation of the situational factors. It attempts to take care of a perplexing and confused issue through utilization of different instruments and methods. These apparatuses and methods attempt to draw out a consistent, exact and logical answer for given issue. [13], [15] ,[17]

\section{SCOPE OF THE STUDY}

Worker Training isn't just a movement that is attractive yet additionally an action than an association must submit assets to .It keeps up a profitable and learning workforce. The extension stretches out to: [14],[16],[18]

Qualities and shortcoming are recognized Developing interest

Complete show of the activity prerequisites

\section{RESEARCH DESIGN}

The examination configuration is the calculated structure inside which research is directed; it comprises the blue print for the gathering, estimation and investigation of information. An exploration configuration incorporates the philosophy and systems utilized to lead logical research. The structure utilized in this examination is unmistakable. [19],[21],[23]

\section{V.STATISTICAL TOOLS}

Charts

Percentage analysis

Weighted average methods Chi-square test

\section{A. Chart}

A diagram is a graphical portrayal of information, wherein "the information is spoken to by bar outlines, line diagram, segment outline, pyramid outline, donut diagram, chamber graph and pie diagrams are utilized for investigation to get an unmistakable thought regarding the organized information[20],[22], [24].

B. Percentage analysis 
Rate investigation alludes to a particular kind which is utilized in making an examination between at least two arrangement of information. Rates depend on expressive relationship. It thinks about the relative things. Since the rate decreases everything to a typical base and along these lines permit meaning examination. Each table has been determined based on rate.

\section{Weighted average method}

This strategy is broadly utilized in finding the weight age given to various properties by respondents. The respondents relegate diverse weight age to the distinctive positioning and weighted normal rate is found

\section{Chi - square test analysis}

The chi-square test a genuinely, basic and certainly the most mainstream of the various devices, the chi-square test is most broadly utilized non-parametric tests in factual work. It makes no supposition about being examined. The amount chi-square portrays the size of inconsistency among hypothesis and perception.

$$
\chi^{2}=\Sigma(O i j-E i j)^{2} / E i j
$$

\section{LIMITATIONS}

The exploration study was led inside a constrained term of time, so a point by point and complete investigation couldn't be made.

A portion of the respondents are not clear with the appropriate response.

The answers given by the representatives could have been covered because of workplace of the organization.

The understanding given by one respondents varies from others and the appropriate response given by respondents may just be estimated.

The discoveries are considerably founded on data given by the respondents and much of the time, abstract inclination can't be completely precluded. [31],[33]

Table -1 Respondents based on agree with the training method focus on developing team work and leadership skills

\begin{tabular}{|c|c|c|c|}
\hline S. No & Option & $\begin{array}{c}\text { No Of } \\
\text { Respondents }\end{array}$ & $\begin{array}{c}\text { Percentage } \\
\%\end{array}$ \\
\hline 1 & $\begin{array}{c}\text { Strongly } \\
\text { Agree }\end{array}$ & 20 & 17 \\
\hline 2 & Agree & 24 & 20 \\
\hline 3 & Neutral & 21 & 17 \\
\hline 4 & Disagree & 35 & 27 \\
\hline 5 & $\begin{array}{c}\text { Strongly } \\
\text { Disagree }\end{array}$ & 25 & 19 \\
\hline
\end{tabular}

\section{Inference:}

The above table and chart indicates it is inferred that $27 \%$ majority of the respondents are having disagree, $17 \%$ of the respondents are neutral,19\% of the respondents are strongly disagree, $20 \%$ of the respondents are agree

\section{RESULTS AND DISCUSSIONS}

Representatives must be persuaded to take up workers preparing normally to refresh their aptitudes and adapt new system to play out their work viably and productively

Goals of the preparation projects must be in accordance with the need of the learners and must be obviously disclosed to them thus that they can be effectively achieved

Unrivaled nature of preparing materials and preparing helps gave to the learner will expanded their association and interests for the preparation which thus in their exhibitions, viable conveys and to improve great relationship among collaborators

Coaches must broaden their own consideration and worry to make a neighborly environment and consistently be prepared to help the learners in troublesome circumstance

Association take must endeavors to see that learners are given the best of offices brining in new improvement with each preparation program

\section{CONCLUSION}

The examination illuminates the viability and restrictions on representatives preparing project being directed in Aqua care pluz. In view of the discoveries, the administration can upgrade and grow new modules in the preparation and advancement program, so that at last the assets of representatives are used at ideal level. Preparing is a unique asset among the assets of the universe "no preparation no improvement". In this way, preparing and advancement is a piece of any association on the planet. [25],[27],[29]

The new thousand years will be on of information and rivalry. The Aqua care pluz will in this way attempt to make each worker work an energizing one with satisfactory open door for self-improvement. At whatever point a requirement for learning solicitation emerges in the framework the association should find a way to refresh the information and expertise of the workers by sorting out representatives preparing programs. Powerful preparing and advancement assessment procedures are required to quantify change in individual, and group in regard of authoritative productivity and viability. [26],[28],[30]

\section{REFERENCES}

1) BharthVajan R., Ramachandran S.,Psychographic dimensions of training,2016,International Journal of Pharmacy and Technology,V-8,I-4,P-23727-23729

2) Balakrishnan P., Bharthvajan R.,A study on human resource planning in hospitals in Chennai City,2014,International Journal of Applied Engineering Research,V-9,I-22,P-7503-7507

3) Priyadarsini P., Bharthvajan R.,Role of emotional intelligence training programme in reducing the stress of the nurses,2014,International Journal of Applied Engineering Research,V-9,I-22,P-7411-7421

4) Kerinab Beenu G., Bharthvajan R.,Empirical analysis on the cosmetic buying behavior of young women in South India,2014,International Journal of Applied Engineering Research,V-9,I-22,P-7361-7366

5) Balakrishnan P., Bharthvajan R.,Whistling in the wind,2014,International Journal of Applied Engineering Research,V-9,I-22,P-7586-7593

6) Krishnan B., Peter M.,Health hazards of Indian Bpo employee-an alarming issue,2014,International Journal of Applied Engineering Research,V-9,I-22,P-7336-7341

7) Kerinab Beenu G.H., Peter M.,Role

of insurance in economic development,2014,International Journal 
of Applied Engineering Research,V-9,I-22,P-7532-7539

8) Balakrishnan P., Peter M., Priyadarsini P.,Efficiency of safety measures for wellbeing of employees in manufacturing industry,2014,International Journal of Applied Engineering Research,V-9,I-22,P-7376-7382

9) Anbarasi M., Praveen Kumar S.,Online sales promotions of herbal products and its effectiveness towards tanisha.com,2019,Indian Journal of Public Health Research and Development,V-10,I-1,P-195-200

10) Anbarasi M., Praveen Kumar S.,Various online marketing and promotions strategies to improve the validation towards the organic products in the pharmaceutical sectors,2019,Indian Journal of Public Health Research and Development,V-10,I-1,P-263-269

11) Loganathan R., Praveen Kumar S.,Grievance handling a key factor for solving issues of employees in an organization,2014,International Journal of Applied Engineering Research,V-9,I-22,P-7483-7491

12) Loganathan R., Praveen Kumar S.,Study on preference of private label brands in super and Hypermarkets,2014,International Journal of Applied Engineering Research,V-9,I-22,P-7327-7335

13) Smitha M., Praveen Kumar S.,Understanding stress and its managementamong the nurses in Chennai city,2014,International Journal of Applied Engineering Research,V-9,I-22,P-7560-7565

14) Kerinab Beenu G.H., Praveen Kumar S.,A study on the investment behavior of Chennai investors in mutual fund schemes,2014,International Journal of Applied Engineering Research,V-9,I-22,P-7520-7525

15) Loganathan R., Praveen Kumar S.,Retention strategies key for organizational productivity,2014,International Journal of Applied Engineering Research,V-9,I-22,P-7443-7447

16) Pavithra J., Ganesan M., Brindha G.,State wise analysis of microfinance sector in India,2016,International Journal of Pharmacy and Technology,V-8,I-4,P-23417-23432

17) Pavithra J., Ganesan M.,A comparative study on microfinance in India and abroad,2016,International Journal of Applied Business and Economic Research,V-14,I-8,P-5471-5476

18) Pavithra J., Ganesan M.,A study on awareness and impact of micro-financial schemes,2016,International Journal of Applied Business and Economic Research,V-14,I-8,P-5449-5460

19) Senthilmurugan P., Pavithra J.,Consumer preference towards organised retailing with reference to Big Bazaar,2014,International Journal of Applied Engineering Research,V-9,I-22,P-7469-7475

20) Senthilmurugan P., Pavithra J.,Implication of social media marketing in growing healthcare industry,2014,International Journal of Applied Engineering Research,V-9,I-22,P-7448-7456

21) Loganathan R., Pavithra J.,Consumer perception towards private label brand over other brands in super markets and hypermarkets,2014,International Journal of Applied Engineering Research,V-9,I-22,P-7355-7360

22) Kerinab Beenu G., Pavithra J.,Tradeâ€"off between liquidity and profitability in logistics industry,2014,International Journal of Applied Engineering Research,V-9,I-22,P-7398-7401

23) Kerinab Beenu G., Pavithra J.,A study on the prospective consumerâ€ $\mathrm{TM}_{\mathrm{S}}$ perception towards utility cars in Chennai city,2014,International Journal of Applied Engineering Research,V-9,I-22,P-7526-7531

24) Pavithra J., Dilli Babu P., Ambuli T.V.,A study on budgetary control at Maruti Service Masters, Chennai,2014,International Journal of Applied Business and Economic Research,V-12,I-2,P-151-161

25) Pavithra J., Dilli Babu P., Ambuli T.V.,A study on customer satisfaction of retro Garments Pvt Ltd, Chennai,2014,International Journal of Applied Business and Economic Research,V-12,I-2,P-381-391

26) Kerinab Beenu G.H., Pavithra J., Senthilmurugan P.,A study on the influence of promotional activities for TATA ARIA among consumers in Chennai,2014,International Journal of Applied Engineering Research,V-9,I-22,P-7572-7578

27) Vijayaragavan S.P.,An investigative expert that's general FBG sensors,International Journal of Mechanical Engineering and Technology,V-8,I-8,PP-1500-1505,Y-2017

28) Vijayaragavan S.P.,Equalization routing protocol for Wi-Fi sensor strategy,International Journal of Mechanical Engineering and Technology,V-8,I-8,PP-1662-1666,Y-2017

29) Karthik B., Kiran Kumar T.V.U., Vijayaragavan P., Bharath Kumaran E.,Design of a digital PLL using 0.35 $\hat{\mathrm{I}}^{1} / 4 \mathrm{~m}$ CMOS technology,Middle - East Journal of Scientific Research,V-18,I-12,PP-1803-1806,Y-2013

30) Kanniga E., Selvaramarathnam K., Sundararajan M.,Kandigital bike operating system,Middle - East Journal of Scientific Research,V

31) Jasmin M., Vigneshwaran T., Beulah Hemalatha S.,Design of power aware on chip embedded memory based FSM encoding in FPGA,International Journal of Applied Engineering Research,V-10,I-2,PP-4487-4496,Y-2015

32) Jasmin M.,Optimization techniques for low power VLSI circuits,Middle East Journal of Scientific Research,V-20,I-9,PP-1082-1087,Y-2014

33) Jasmin M., Vigneswaran T.,Fuzzy controller for error control of on - Chip communication,2017 International Conference on Algorithms, Methodology, Models and Applications in Emerging Technologies, ICAMMAET 2017,V-2017-January,I-,PP-1-5,Y-2017

\section{AUTHORS PROFILE}

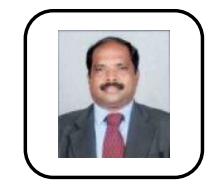

Mr. R. Ramamoorthy Assistant Professor, Department of MBA, Bharath Institute of Higher Education and Research, Chennai, India.

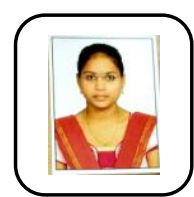

S.S.L Mounika Gayathri Student, Department of MBA, Bharath Institute of Higher Education and Research, Chennai, India.

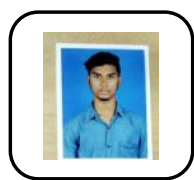

Sanjay Student, Department of MBA, Bharath Institute of Higher Education and Research, Chennai, India. 